\title{
Value of nailfold videocapillaroscopy and high-sensitivity C-reactive protein test in diagnosis of microangiopathy in adolescents with Raynaud's phenomenon
}

\author{
Wartość diagnostyczna wideokapilaroskopii łożyska okołopaznokciowego i testu \\ hsCRP w ocenie subklinicznego zapalenia naczyń u młodocianych pacjentów \\ z objawem Raynauda
}

\author{
Anna Górska ${ }^{1,2}$, Marta Bartnicka ${ }^{1}$, Lidia Rutkowska-Sak ${ }^{3}$ \\ ${ }^{1}$ Department of Family Medicine and Community Nursing, Medical University of Białystok \\ 2University Children's Clinical Hospital, Capillaroscopy Laboratory \\ ${ }^{3}$ Developmental Age Rheumatology Department, Institute of Rheumatology in Warsaw \\ 'Zakład Medycyny Rodzinnej i Pielęgniarstwa Środowiskowego Uniwersytetu Medycznego w Białymstoku \\ 2Pracownia Kapilaroskopowa Uniwersyteckiego Dziecięcego Szpitala Klinicznego \\ ${ }^{3}$ Klinika Reumatologii Wieku Rozwojowego Instytutu Reumatologii im. prof. dr hab. med. Eleonory Reicher w Warszawie
}

Key words: Raynaud's phenomenon, videocapillaroscopy, hsCRP, microangiopathy.

Stowa kluczowe: objaw Raynauda, wideokapilaroskopia, hsCRP, mikroangiopatia.

\section{Sum mary}

Introduction: Nailfold videocapillaroscopy allows assessment of structural abnormalities in the peripheral microcirculation in patients with Raynaud's syndrome (RS), whereas an increased level of highsensitivity C-reactive protein (hSCRP) is an acknowledged marker of even low-intensity inflammation of vascular endothelium in many autoimmune diseases, and also in atherosclerosis.

Objective: Assessment of capillaroscopic structural abnormalities in microcirculation with regard to the duration of Raynaud's phenomenon (RP), the level of hsCRP and the presence of ANA in the serum of children and adolescents with RS.

Material and methods: The study involved 144 patients (104 girls and 40 boys) at the mean age of $16.07 \pm 3.66$ years, who had undergone at least two capillaroscopies. The study patients were divided into 3 groups depending on RP duration ( $\leq 2$ years, $2-5$ years and over 5 years). A STEMI 2000 capillaroscope (ZEISS) was used. Capillaries were measured using the computer program NIS-Elements D2.30 Nikon Corp. Japan. Capillary loops wider than $50 \mu \mathrm{m}$ were considered dilated. In 59 patients with abnormal patterns of microvessels and low classical inflammatory markers, hsCRP was determined using the immunoturbidimetric method by means of a HITACHI 912 analyser. Results: Secondary RS was diagnosed in 43 (39.8\%) and primary RP in 101 (70.2\%) patients. Disorders in capillaroscopic pictures were more

\section{Streszczenie}

Wstęp: Wideokapilaroskopia wału przypaznokciowego umożliwia ocenę strukturalnych zaburzeń mikrokrążenia obwodowego u pacjentów z zespołem Raynauda (ZR).

Zwiększenie stężenia białka C-reaktywnego, oznaczanego metodą wysokiej czułości (high sensitivity C-reactive protein - hsCRP), jest natomiast uznanym wyznacznikiem zapalnej aktywacji lub dysfunkcji śródbłonka naczyniowego w wielu schorzeniach z autoimmunizacji, a także w miażdżycy, zwłaszcza w jej przedklinicznym stadium.

Cel pracy: Ocena zmian kapilaroskopowych w odniesieniu do czasu trwania objawu Raynauda oraz analiza zależności pomiędzy stężeniem hsCRP a ilościowymi i jakościowymi zaburzeniami mikrokrążenia obwodowego u dzieci i młodzieży z ZR.

Materiał i metody: Analizie poddano 144 pacjentów (104 dziewczęta i 40 chłopców) w średnim wieku 16,07 $\pm 3,66$ roku, u których co najmniej dwukrotnie wykonano badanie kapilaroskopowe. Badanych podzielono na 3 grupy w zależności od czasu trwania objawu Raynauda ( $\leq 2$ lat, $2-5$ lat $\mathrm{i}>5$ lat). Badania przeprowadzano przy użyciu kapilaroskopu STEMI 2000 Firmy ZEISS. Pomiarów kapilar dokonano za pomocą programu komputerowego NIS-Elements D2.30 Nikon Corp. Japan. Pętle kapilar szersze niż 50 um uznano za poszerzone. U 59 pacjentów z obecnymi nieprawidłowymi wzorami mikronaczyń i stwierdzonymi niskimi klasycznymi wskaźnikami zapal- 
enhanced in patients with longer disease duration $(p<0.01)$. The mean levels of hsCRP $(0.44 \pm 0.47 \mathrm{mg} / \mathrm{dl})$ correlated significantly with patients' age and RS duration. The mean width of the arterial arm (35.4 $\pm 11.4 \mu \mathrm{m})$ and venous arm $(45.3 \pm 26.5 \mu \mathrm{m})$ correlated significantly with the mean level of hsCRP $(p<0.05)$.

Conclusions: In patients with Raynaud's syndrome, structural abnormalities in microcirculation, together with elevated level of hsCRP, suggest the presence of subclinical vasculitis, with possible endothelial dysfunction.

Further investigation into impairment of microcirculation in patients with secondary Raynaud's syndrome could support the therapeutic option oriented at suppressing proinflammatory and prothrombotic endothelial activation.

\section{Introduction}

The presence of Raynaud's phenomenon in adolescent patients often raises concerns and leads to seeking help from many doctors. It is characterized by sudden and recurring episodes of blanching of the fingers following which they turn blue in response to cold or stress. Raynaud's phenomenon may be primary in character (Raynaud's disease) - accounting for approx. $80 \%$ of cases - or secondary, also known as Raynaud's syndrome - generally a manifestation of an underlying connective tissue disorder [1, 2].

The pathophysiological mechanisms responsible for Raynaud's phenomenon have not yet been fully determined. In recent years, researchers have emphasized the significance of damage/dysfunction of the vascular endothelium, induced by local hypoxia [3, 4]. Chronic endothelial activation may result in the release, by the endothelium, of excessive amounts of substances that cause constriction of the vessels of the microcirculation (e.g. endothelins and E-selectins) as well as reduced production of myorelaxing and anti-thrombotic factors (nitric oxide, prostacyclin) [5, 6]. This has been confirmed in studies of biochemical markers of inflammation and endothelial dysfunction, including adhesions and chemokines in autoimmune diseases and many peripheral vascular disorders (atherosclerosis, hypertension, diabetic microangiopathy) [7-11].

These determinations are, however, rarely performed in everyday clinical practice. Determination of C-reactive protein values using an ultrasensitive method - high-sensitivity CRP (hsCRP) - is a less expensive and labour-intensive investigation. It has been established that a local process in the vessel wall produces a systemic inflammatory response that manifests through increased production of acute-phase proteins, mainly C-reactive protein by hepatocytes, further promoting inflammatory and thrombotic reactions. An association between elevated hsCRP con- nymi oznaczono hsCRP metodą immunoturbidymetryczną przy użyciu HITACHI 912

Wyniki: Wtórny ZR rozpoznano u 43 pacjentów (39,8\%), a pierwotny objaw Raynauda (PR) u 101 (70,2\%) osób. Zaburzenia w obrazach kapilaroskopowych były bardziej nasilone u pacjentów z dłuższym czasem trwania choroby $(p<0,01)$. Średnie stężenie hsCRP $(0,44 \pm 0,47 \mathrm{mg} / \mathrm{dl})$ istotnie dodatnio korelowało z wiekiem pacjentów i czasem trwania

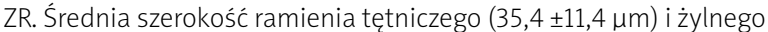
$(45,3 \pm 26,5 \mu \mathrm{m})$ istotnie dodatnio korelowały ze średnim stężeniem hsCRP $(p<0,05)$.

Wnioski: U pacjentów z zespołem Raynauda stwierdzenie zaburzeń strukturalnych mikronaczyń w badaniu kapilaroskopowym jednocześnie ze zwiększonym stężeniem hsCRP sugeruje obecność subklinicznego vasculitis, z możliwą aktywacją śródbłonka.

Dalsze badania strukturalnych i czynnościowych zaburzeń mikrokrążenia u pacjentów z wtórnym ZR mogłyby wspomóc działania ukierunkowane na hamowanie prozapalnej i prozakrzepowej aktywacji śródbłonka.

centrations and acute coronary syndromes, cerebral stroke and diabetic microangiopathy has been proven. Furthermore, some researchers have suggested that hsCRP is the leading marker of the inflammatory process that accompanies the development of atherosclerosis in its preclinical stage, stronger, and perhaps even more objective than classic lipid parameters [8, 12].

Therefore, it appears plausible that elevated hsCRP concentrations in patients with Raynaud's phenomenon could be a prognostic indicator for inflammatory damage of the vessels of the microcirculation long before the appearance of clinical symptoms of one of the scleroderma spectrum diseases on the one hand and premature atherosclerosis on the other [13].

The monitoring of morphological abnormalities in capillary vessels and vascular flow using videocapillaroscopy, particularly in patients with long-standing Raynaud's phenomenon, may also provide an indirect indication of the presence of dysfunction and/or inflammatory endothelial activation within the vessels of the microcirculation $[14,15]$. The videocapillaroscopic examination is non-invasive and inexpensive, thus allowing multiple re-testing. Meanwhile, computerized analysis of images of the microcirculation and the possibility of data storage enable assessment of the dynamics of changes taking place over time [16].

The purpose of the study was to assess changes in capillaroscopic images in children and adolescents with Raynaud's phenomenon in relation to the duration of Raynaud's phenomenon and serum hsCRP concentrations.

\section{Material and methods}

The analysis was conducted on 144 patients (104 girls and 40 boys) aged $5-22$ years (mean age: $16.07 \pm 3.66$ years), who had attended the Rheumatological Clinic in the years 2000-2010 and had undergone at least 2 nailfold 
capillaroscopies of the fingers because of the presence of signs of Raynaud's phenomenon. In patients with primary Raynaud's phenomenon, follow-up investigations were repeated at intervals of $6-12$ months whereas in patients with secondary Raynaud's phenomenon, associated with a systemic connective tissue disease, they were repeated at intervals of 3-6 months. Approval for the study was obtained from the Bioethics Committee of the Medical University of Białystok.

Study subjects were divided into 3 groups depending on the duration of the disease ( $\leq 2$ years, $2-5$ and $>5$ years).

Nailfold capillaroscopy of the fingers of both hands was performed following a period of acclimatization lasting at least 20 minutes, in an isolated room where the temperature was maintained at a constant $20-22^{\circ} \mathrm{C}$. A drop of cedar wood oil was deposited on the examined finger in order to improve light penetration. The source of light, shone at an angle of $45^{\circ}$, was a KLD 1500 LCD lamp (ZEISS). Testing was conducted using the STEMI 2000 capillaroscope (ZEISS). In order to obtain measurements, capillary images captured on photographs were recorded on a computer hard drive (tests were performed by the first author - A.G.).

Capillary morphology was evaluated by examining the capillaries of the nailfold of fingers 2 to 4 of both hands. An abnormal image was defined as an image with over 2 irregular (tortuous and branched) vascular loops in each examined finger. Features such as a decreased number of capillaries (a deficit of 2 or more in 1 finger) and avascular areas in at least one finger were described as microangiopathy characteristic of scleroderma [17].

Using the NIS-ELEMENTS D2.30 computer software from Nikon Corporation Japan, Researcher II (M.B.) evaluated capillary parameters such as the number of capillaries and the diameter of the arterial and venous limbs of the capillary loop using registered capillaroscopic images of the $4^{\text {th }}$ finger of the left hand. Capillary loops exceeding $50 \mu \mathrm{m}$ in diameter were described as dilated [18].

In 59 patients with low classic inflammatory process parameter values (43 with secondary RP and 16 with primary RP), hsCRP was determined during the course of the last capillaroscopic examination analysed in this study, using a latex enhanced immunoturbidimetric assay in a HITACHI 912 biochemical analyser (Department of Paediatric Laboratory Diagnostics, UDSK). The normal range of hsCRP was determined as $0-0.5 \mathrm{mg} / \mathrm{dl}$.

\section{Statistical analysis}

A statistical analysis of the results was performed; for quantifiable parameters the following were calculated: mean minimum value, maximum value and standard deviation. Student's t-test was used for variables that met the criteria of normal distribution. The Mann-Whitney U-test was used to analyse variables that did not meet the criteria of normal distribution. A correlation analysis was conducted using Pearson's linear correlation test. Differences with $p<0.05$ were considered statistically significant. The statistical analysis was performed using the Statistica 8.0 software from StatSoft.

\section{Results}

Secondary Raynaud's phenomenon was diagnosed in 43 (39.8\%) patients (in 25 with localized scleroderma, 2 with limited systemic sclerosis, 2 with juvenile idiopathic arthritis and 14 with an undifferentiated connective tissue disease). The remaining patients were diagnosed with primary Raynaud's phenomenon - 101 (70.2\%). The duration of Raynaud's phenomenon was 2 to 10 years, mean duration was $4.62 \pm 2.06$ and was longer in the group with secondary RP $(5.70 \pm 4.18$ years $)$.

The results of inflammatory process marker determinations (ESR, CRP) in all of the participants remained within normal limits. ELISA assays for the presence of antinuclear antibodies (Index ANA 0-0.8 - negative result; 0.9 to 1.2 - borderline; above 1.2 - positive result) were performed in 98 patients (67.9\%); 10 patients (10.2\%) were found to have elevated titres. Qualitative and quantitative changes in capillary walls and hsCRP and ANA values are presented in Table I. The presence of capillaries with

Table I. General description of the study groups and of capillaroscopic data: Group A - Raynaud's phenomenon, Group B - Raynaud's syndrome

\begin{tabular}{|c|c|c|}
\hline Parameters & $\begin{array}{c}\text { Group A } \\
(N=101)\end{array}$ & $\begin{array}{l}\text { Group B } \\
(N=43)\end{array}$ \\
\hline age (years) ${ }^{1}$ & $16.60 \pm 4.16$ & $16.13 \pm 3.37$ \\
\hline disease duration (years) ${ }^{1}$ & $4.73 \pm 2.43$ & $5.70 \pm 4.18$ \\
\hline $\operatorname{hsCRP}(\mathrm{mg} / \mathrm{dl})^{1}$ & $0.28 \pm 0.32^{*}$ & $0.49 \pm 0.52$ \\
\hline \multicolumn{3}{|l|}{ number } \\
\hline ANA $\geq 1$ & $0.42 \pm 0.44$ & $0.49 \pm 0.465$ \\
\hline$(n / \%)$ & $3 / 2.9$ & $7 / 16.3$ \\
\hline \multicolumn{3}{|l|}{ number/percentage (n/\%) } \\
\hline presence of irregular loops & $24 / 23.8$ & $36 / 83.4$ \\
\hline $\begin{array}{l}\text { enlarged loops }(>50 \mu \mathrm{m}) \\
>2 / \text { finger }\end{array}$ & $62 / 61.4$ & $39 / 90.7$ \\
\hline presence of spastic loops & $3 / 2.9$ & $7 / 16.3$ \\
\hline $\begin{array}{l}\text { reduced number of capillaries } \\
\text { (loss) reduction }\end{array}$ & $0 / 0$ & $11 / 25.6$ \\
\hline
\end{tabular}

${ }^{1}$ Data are presented as means $\pm S D$

${ }^{*} p<0.05$ compared to Group B 
Table II. Qualitative and quantitative disorders of capillary formation and measurement of hsCRP and ANA, depending on the duration of Raynaud's phenomenon (PR)

\begin{tabular}{|lccc|}
\hline Parameters & $\begin{array}{c}\text { PR duration } \\
(\text { years }) \leq 2 \\
(n=16)\end{array}$ & $\begin{array}{c}\text { PR duration } \\
(\text { years }) 2 \leq 5 \\
(n=61)\end{array}$ & $\begin{array}{c}\text { PR duration } \\
(\text { years })>5 \\
(n=67)\end{array}$ \\
\hline age (years) ${ }^{1}$ & $14.17 \pm 3.35$ & $17.59 \pm 2.48$ & $17.08 \pm 3.44$ \\
\hline hsCRP1 & $021 \pm 0.04^{* *}$ & $0.39 \pm 0.31^{*}$ & $0.94 \pm 0.98$ \\
& $0.76 \pm 0.74$ & $0.46 \pm 0.43$ & $0.53 \pm 0.64$ \\
\hline $\begin{array}{l}\text { number/percentage }(n / \%) \\
\text { presence of } \\
\text { irregular loops }\end{array}$ & $5 / 31.25$ & $26 / 42.62$ & $43 / 64.18$ \\
\hline $\begin{array}{l}\text { width of loops } \\
>50 \mu m\end{array}$ & $4 / 25.00$ & $28 / 45.90$ & $35 / 52.24$ \\
\hline spastic loops & $3 / 18.75$ & $10 / 16.39$ & $27 / 40.30$ \\
\hline
\end{tabular}

${ }^{1}$ Data are presented as means $\pm S D$

${ }^{*} p<0.05$ compared to group $>5$ years duration

${ }^{* *} p<0.01$ compared to group $>5$ years duration

an irregular course (tortuous, branched capillaries) was observed in $83.4 \%$ of participants with secondary RP compared to $23.8 \%$ of children with primary RP. Determination of the diameter of both the arterial and venous limbs revealed a high proportion (61.4\%) of dilated capillaries (> $50 \mu \mathrm{m}$ ) in patients with primary RP. Abnormal capillaroscopic findings in the form of irregular, dilated and spastic capillaries were more marked in patients with a longer history of Raynaud's phenomenon (Table II). Serum hsCRP concentrations were determined in 7 patients with a history of RP of less than 2 years, in 20 patients who had had RP for 2 to 5 years and in 35 who had had RP for a period of over 5 years. Serum hsCRP concentrations ranged

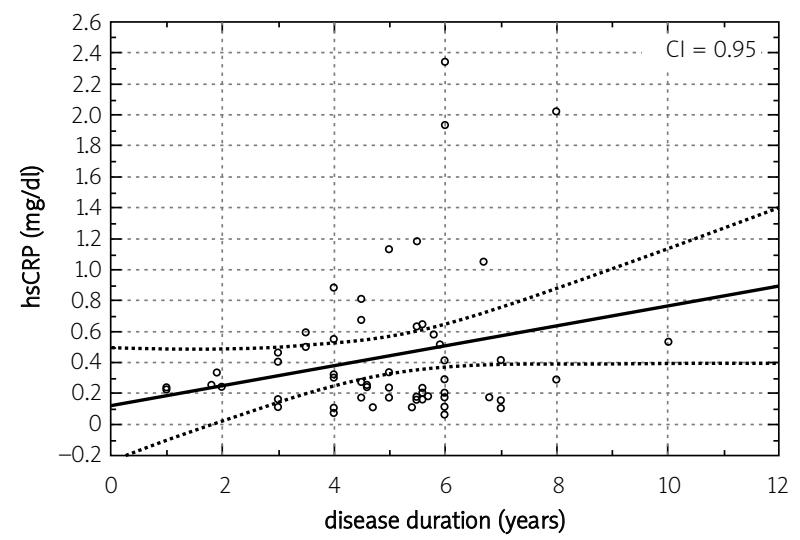

Fig. 1. Average concentration of hsCRP in patients studied. from 0.06 to $2.34 \mathrm{mg} / \mathrm{dl}$; mean value: $0.49 \pm 0.52 \mathrm{mg} / \mathrm{dl}$. Eighteen patients (30.5\%) had hsCRP values exceeding 0.5 $\mathrm{mg} / \mathrm{dl}$. Mean hsCRP concentrations in study participants demonstrated a significant positive correlation with the duration of Raynaud's phenomenon (Fig. 1). In addition, the mean diameter of the arterial and venous limbs showed a significant positive correlation with the mean hsCRP concentration (Table III).

\section{Discussion}

In most young patients, Raynaud's phenomenon follows a benign course. However, given the risk of development of a systemic connective tissue disease, early identification of patients with secondary Raynaud's phenomenon is very important $[19,20]$.

The predictive value of capillaroscopy in patients with Raynaud's phenomenon with regard to development of systemic connective tissue diseases has been emphasised in numerous publications [21, 22]. The presence of a decreased number of capillaries, dilated vascular loops, leading to the development of giant capillaries, avascular areas and structural alterations was described by Maricq et al. as microangiopathy characteristic of scleroderma (scleroderma-pattern of capillary abnormalities) [2, 23].

Our studies have shown that among 144 children and adolescents with Raynaud's phenomenon and low values of classic inflammatory process markers, almost $1 / 3$ was diagnosed with secondary Raynaud's phenomenon within a 10-year follow-up period (average duration of secondary RP was $5.7 \pm 4.2$ years). The capillaroscopic images of the majority of these patients showed signs of a characteristic scleroderma pattern of capillary abnormalities - the benign "slow" pattern, as described by Maricq et al. - while a decrease in the number of vessels (a deficit of two or more capillaries per finger) was observed in 11 patients (25.6\%) with secondary RP.

The remaining 101 patients were diagnosed with primary Raynaud's phenomenon. An analysis of capillaroscopic images obtained in this study group revealed abnormalities in vascular morphology and distribution in

Table III. Correlations between width of the capillary and hsCRP

\begin{tabular}{|lcc|}
\hline Parameters & $\begin{array}{r}\text { hsCRP (means } \pm \text { SD) } \\
(0.44 \pm 0.47 \mathrm{mg} / \mathrm{dl})\end{array}$ \\
\cline { 2 - 3 } & \multicolumn{1}{c|}{$r$} & $p$ \\
\hline $\begin{array}{l}\text { width of arterial limb } \\
\text { mean } \pm \text { SD } 35.4 \pm 11.4 \mu \mathrm{m}\end{array}$ & 0.12 & $<0.05$ \\
\hline $\begin{array}{l}\text { width of venous limb } \\
\text { mean } \pm \text { SD } 45.3 \pm 26.5 \mu \mathrm{m}\end{array}$ & 0.14 & $<0.05$ \\
\hline
\end{tabular}


approx. 20\% of participants; nevertheless, none of the patients with primary RP were seen to have a decreased number of capillaries (avascular areas). However, the majority of these patients (62\%) were found to have 2 or more significantly dilated vascular loops (exceeding $50 \mu \mathrm{m}$ ) per finger, which is not consistent with observations by other authors $[1,16]$, according to which primary $\mathrm{RP}$ is characterized by the presence of loops arranged in parallel whose shape and morphology are normal. We feel that the increased number of dilated capillaries seen in our study is associated with the fact that measurements were carried out on both the arterial and venous limbs. According to some researchers, in a large proportion of children, even healthy children, the descending arm (venous branch) may be dilated and have an irregular course $[24,25]$. Nonetheless, a particularly detailed and comprehensive assessment of the dynamics of these vascular changes is indicated in this group of young patients with primary RP in the course of follow-up capillaroscopic investigations.

Published literature emphasises the importance of the description of the vascular stroma in capillaroscopic studies [9]; a statistical analysis of this was not performed in our study. It should therefore be added that, on the one hand, assessment of stromal pathology in children and adolescents is difficult and ambiguous, while on the other, it is the number and degree of capillary filling, as well as morphological abnormalities, that reflect the level of skin nourishment and are associated with metabolic processes of the microcirculation [2], which may indirectly affect vascular endothelial function.

In clinical practice, establishing a reliable diagnosis in children and adolescents with Raynaud's phenomenon is difficult, as confirmed in studies by Hirschl et al. [26]. The authors discovered that $20 \%$ of patients initially diagnosed as having primary Raynaud's phenomenon were diagnosed with secondary Raynaud's phenomenon in the course of the subsequent 10 years [27]. Meanwhile, following an analysis of capillaroscopic results and clinical data, Cutolo et al. [28] observed that, out of the 129 patients initially classified as having primary RP, 19 (14.7\%) developed secondary Raynaud's phenomenon within an average period of $29.4 \pm 10$ months.

An interesting issue was the attempt to answer the question of whether an association exists between abnormal capillaroscopic images obtained from patients with primary and secondary RP and the subclinical inflammatory process in microvessels and, given the inflammatory basis of atherosclerosis, whether increased hsCRP values signal a risk of the development of premature atherosclerosis in young adults.

Many researchers agree hsCRP is a precise indicator of endothelial cell activation to express ICAM-1 adhesion mol- ecules or the production of VCAM-1 and E-selectin, which may lead to the development of inflammation in the vessels of both the micro- and the macrocirculation. CRP also induces production of MCP-1, a monocyte chemotactic protein (inhibited by statins and fibrates) $[12,28]$. It is highly probable that inflammation in the vessels of the peripheral microcirculation, even if this process takes a subclinical course (low grade inflammatory state), will produce consequences in the form of functional as well as structural microvascular abnormalities, as studies in children with other disorders have demonstrated [29, 30].

Mean hsCRP concentrations obtained in our study were significantly higher in patients with secondary RP compared to values obtained in patients with primary RP (Table I). Moreover, in patients who had had Raynaud's phenomenon for over 5 years, mean hsCRP concentrations were significantly higher compared with patients with a shorter history of Raynaud's phenomenon (Table II). Furthermore, studies have shown a significant positive correlation between hsCRP concentration and the diameter of both the arterial and venous limbs of examined capillaries. It should be emphasised that despite structural aberrations in microcirculation and elevated hsCRP values, none of the patients in the study group experienced digital ulcers or necrosis, which suggests that the immune-inflammatory process may develop insidiously within vessel walls over a period of many years.

In summary, our studies and studies by other authors indicate that in adolescent patients with Raynaud's phenomenon, nailfold videocapillaroscopy is a non-invasive and useful tool for monitoring the development of the disorder, and should be repeated at least every 6-12 months. The presence of one or more abnormal capillaroscopic images (primarily the type of pattern known as scl pattern) should draw doctors' attention to the possibility of development of connective tissue diseases. The inexpensive and repeatable test determining serum hsCRP concentrations may prove useful for simultaneous assessment of subclinical inflammation, along with possible endothelial activation, in the vessels of the microcirculation (low grade inflammatory state).

Further studies into microvascular dysfunction using non-invasive videocapillaroscopic methods combined with simultaneous evaluation of biochemical markers of inflammation and endothelial dysfunction (including hs(RP) could help identify the group of patients affected by microangiopathy, but with coexisting vasculitis in its preclinical stage, as well as patients at risk of developing premature atherosclerosis. The results of these studies would provide support for the experimental administration of endothelial-active drugs, such as statins or platelet aggregation inhibitors, particularly in patients with secondary Raynaud's phenomenon. 


\section{Authors declare no conflict of interests.}

\section{References}

1. LeRoy EC, Medsger TA. Raynaud's phenomenon: a proposal for classification. Clin Exp Rheumatol 1992; 10: 485-488.

2. Maricq HR, Volter I. A working classification of scleroderma spectrum disorders: a proposal and the results of testing on a sample of patients. Clin Exp Rheumatol 2004; 22 (3 Suppl 33): S5-13.

3. Bakst R, Merola JF, Franks AGJr, Sanchez M. Raynaud's phenomenon: pathogenesis and management. J Am Acad Dermatol 2008; 59: 633-653.

4. Baumhäkel M, Böhm M. Recent achievements in the management of Raynaud's phenomenon. Vasc Health Risk Manag 2010; 6: 207-214.

5. Kaplan MJ. Endothelial damage and autoimmune diseases. Autoimmunity 2009; 42: 561-562.

6. Kim HS, Park MK, Kim HY, Park SH. Capillary dimension measured by computer-based digitalized image correlated with plasma endothelin-1 levels in patients with systemic sclerosis. Clin Rheumatol 2010; 29: 247-254.

7. Sulli A, Soldano S, Pizzorni C, et al. Raynaud's phenomenon and plasma endothelin: correlations with capillaroscopic patterns in systemic sclerosis. J. Rheumatol 2009; 36: 1235-1239.

8. Szekanecz Z, Koch AE. Vascular endothelium and immune responses: implications for inflammation and angiogenesis. Rheum Dis Clin North Am 2004; 30: 97-114.

9. Kuryliszyn-Moskal A, Ciołkiewicz M, Klimiuk PA, et al. Clinical significance of nailfold capillaroscopy in systemic lupus erythematosus: correlation with endothelial cell activation markers and disease activity. Scand J Rheumatol 2009; 38: 38-45.

10. Groner JA, Joshi M, Bauer JA. Pediatric precursor of adult cardiovascular disease: noninvasive assessment of early vascular changes in children and adolescents. Pediatrics 2006; 118: 1683-1691.

11. Górska A, Kowal-Bielecka O, Urban M, et al. Impairment of microcirculation in juvenile idiopathic arthritis - studies by nailfold videocapillaroscopy and correlation with serum levels of sICAM and VEGF. Folia Histochem Cytobiol 2008; 46: 443-447.

12. Ridker PM. High-sensivity C-reactive protein, inflammation, and cardiovascular risk: from concept to clinical practice to clinical benefit. Am Heart J 2004; 148: S19-26.

13. Lambova SN, Müller-Ladner U. The specificity of capillaroscopic pattern in connective autoimmune diseases. A comparison with microvascular changes in diseases of social importance: arterial hypertension and diabetes mellitus. Mod Rheumatology 2009; 19: 600-665.

14. Anderson ME, Allen PD, Moore T, Hillier V, Taylor CJ, Herrick AL. Computerized nailfold video capillaroscopy - a new tool for assessment of Raynaud's phenomenon. J Rheumatol 2005; 32: 841-848.

15. Cutolo M, Sulli A, Secchi ME. Nailfold capillaroscopy is useful for the diagnosis and follow-up of autoimmune rheumatic diseases. A future tool for the analysis of microvascular heart involvement? Rheumatol (Oxford) 2006; 45:suppl. 4: IV43-IV46.

16. Kuryliszyn-Moskal A, Kowal-Bielecka O: Kapilaroskopia. Przegl Reumatol 2006; 2 (4): 9-11.
17. Ingegnoli F, Zeni S, Gerloni V, Fantini F. Capillaroscopic observations in childhood rheumatic diseases and healthy controls. Clin Exp Rheumatol 2005; 23: 905-911.

18. Bollinger A, Fagrell B. Clinical Capillaroscopy. Hogrefe \& Huber Publishers, Toronto-Stuttgart 1990; 77-92.

19. Luggen M, Belhorn L, Evans T, et al. The evolution of Raynaud's phenomenon: a longterm prospective study. J Rheumatol 1995; 22: 2226-2232

20. Koenig M, Joyal F, Fritzler MJ, et al. Autoantibodies and microvascular damage are independent predictive factors for the progression of Raynaud's phenomenon to systemic sclerosis. Arthritis Rheum 2008; 58: 3902-3912.

21. Kuryliszyn-Moskal A, Klimiuk PA, Sierakowski S, et al. Vascular endothelial growth factor in systemic lupus erythematosus: relationship to disease activity, systemic organ manifestation, and nailfold capillaroscopic abnormalities. Arch Immunol Ther Exp 2007; 55: 179-185.

22. Fitzgerald O, Hess EV, O'Connor GT, Spencer-Green G. Prospective study of the evolution of Raynaud's phenomenon. Am J Med 1988; 84: 718-726.

23. Herrick AL, Cutolo M. Clinical implications from capillaroscopic analysis in patients with Raynaud's phenomenon and systemic sclerosis. Arthritis Rheum 2010; 62: 2595-2604.

24. Pavlov-Dolijanovic S, Damjanov N, Ostojic P, et al. The prognostic value of nailfold capillary changes for the development of connective tissue disease in children and adolescents with primary raynaud phenomenon: a follow-up study of 250 patients. Pediatr Dermatol 2006; 23: 437-442.

25. Herrick AL, Moore T, Hollis S, Jayson MI. The influence of age on nailfold capillary dimensions in childhood. J Rheumatol 2000; 27: 797-800.

26. Hirschl M, Hirschl K, Lenz M, Katzenschlager R, Hutter HP, Kundi M. Transition from primary Raynaud's phenomenon to secondary Raynaud's phenomenon identified by diagnosis of an associated disease: results of ten years of prospective surveillance. Arthritis Rheum 2006; 54: 1974-1981.

27. Cutolo M, Pizzorni C, Sulli A. Identification of transition from primary Raynaud's phenomenon to secondary Raynaud's phenomenon by nailfold videocapillaroscopy: comment on the article by Hirschl et al. Arthritis Rheum 2007; 56: 2102-2103.

28. Juonala M, Viikari JS, Ronnemaa T, et al. Childhood C-reactive protein in predicting CRP and carotid intima-media thickness in adulthood: the Cardiovascular Risk in Young Finns Study. Arterioscler Thromb Vasc Biol 2006; 26: 1883-1888.

29. Järvisalo MJ, Harmoinen A, Hakanen $M$, et al. Elevated serum Creactive protein levels and early arterial changes in healthy children. Arterioscler Thromb Vasc Biol 2002; 22: 1323-1328.

30. Blake GJ, Rifai N, Buring JE, Ridker PM. Blood pressure, C-reactive protein, and risk of future cardiovascular events. Circulation 2003; 108: 2993-2999. 